\title{
Santidade cristã hoje Uma reflexão teológica e o Testemunho de Edith Stein
}

Orientadora: Prof . Dra. Lucia Pedrosa de Pádua lpedrosa@puc-rio.br

Pesquisadora: Natália Gomes Faustino

nathyfaustino@bol.com.br

Projeto de Pesquisa: Mística e Humanização na Espiritualidade Cristã Fonte: $\mathrm{CNPq}$

A pesquisa tinha o objetivo de clarificar o que realmente é a santidade cristã. Este objetivo principal se desdobrou em dois objetivos específicos. Primeiramente, desenvolver uma reflexão teológica sobre a santidade cristã, santidade esta que é de Jesus Cristo, pois está e deve estar pautada neste modelo da santidade. Num segundo momento, estudar a vida de uma santa, precisamente Irmã Teresa Benedita da Cruz, mais conhecida por Edith Stein, identificando as contribuições mais significativas deste testemunho que qualificam uma reflexão e vivência da santidade-humanização para o contexto atual. 